\title{
IMPLEMENTASI PENDIDIKAN AGAMA ISLAM BERBASIS MULTIKULTURAL DALAM MEMBANGUN KERUKUNAN BERAGAMA PESERTA DIDIK
}

\author{
Asrul Anan \\ Program Doktor Pendidikan Islam Multikulural \\ Pascasarjana Universitas Islam Malang \\ Email : asrulanan178@gmail.com
}

\begin{abstract}
Abstrak
Nilai-Nilai Multikultural di Sekolah Menengah Atas Negeri 1 Tosari dan Sekolah Menengah Atas SPI memiliki nilai yang sama, walaupun terletak pada basis lingkungan yang berbeda. Adapun nilai tersebut meliputi; keimanan, ketaqwaan, keikhlasan, syukur, sabar, demokrasi, keadilan, kesetaraan, inklusif, kemanusiaan, taaruf, tasamuh, ta ${ }^{\text {ec } w u n, ~ t a w a z u n, ~}$ kekeluargaan, cinta tanah air dan nasionalisme. Proses Internalisasi NilaiNilai Multikultural Dalam Membangun Kerukunan Beragama Peserta didik sama-sama melalui: (a) moral knowing (b) moral feeling, (c) moral action, dan (d) moral transenden. Model internalisasi nilai di Sekolah Menengah Atas Negeri 1 Tosari dalam bentuk sinergitas lingkungan masyarakat dengan lingkungan sekolah yang sangat kuat sehingga mampu membentuk karakter siswa dalam membangun kerukunan beragama peserta didik. Sedangkan model internalisasi di Sekolah Menengah Atas SPI Batu dilakukan melalui sinergi kegiatan dan program yang ada di (1) asrama, (2) kelas, (3) lingkungan sekolah, (4) transformer center, dan (5) spiritual garden, yang dibiasakan secara integrative melalui metode penilaian PAKSA.
\end{abstract}

Kata kunci: implementasi, berbasis multikultural, kerukunan beragama

\section{Abstract}

The multicultural values in the 1 Tosari High school and high school good morning Indonesia have the same value, although it is located on different environmental bases. The value includes; Faith, obedience, steadfast, sincerity, gratitude, patience, democracy, justice, equality, inclusive, humanity, Taaruf, Tasamuh, taawun, Tawazun, family, love of homeland and nationalism. The internalization process of multicultural values in building a religious harmony of learners through: (a) moral knowing (b) moral feeling, (c) moral action, and (d) the moral transcendent. The Model internalization of value in the state Senior High School 1 Tosari in the form of synergity of the community with a very strong school environment that is able to form the character of students in building a harmony of religious 
learners. While the internalization model in the SPI Batu High School is conducted through synergies of activities and programs that exist in (1) dormitories, (2) classes, (3) school environment, (4) transformer Center, and (5) spiritual garden, which is familiarize by integrative Through the PAKSA assessment method.

Keywords: implementation, multicultural based, religious harmony

\section{PENDAHULUAN}

SMAN 1 Tosari memiliki keunikan tersendiri baik dari atmosfir akademik maupun budaya sekolah yang begitu toleran, kerukunan beragama peserta didik di sekolah inipun sangat terjaga dan kondusif walaupun perbandingan jumlah murid dari penganut agama yang ada yaitu Islam dan Hindu sekitar 51; $49 \%$. Dengan realitas perbandingan jumlah peserta didik seperti tersebut malahan menjadikan atmosfir akademik dan budaya sekolah di sekolah ini menjadi sangat toleran, rukun dan damai. Kalau dilihat dari data statistik jumlah siswa yang ada bahwa pada tahun pendidikan 2019 ini jumlah siswa yang berjumlah 173 peserta didik dengan rincian 90 Islam, 82 Hindu dan 1 kristen. ${ }^{1}$

Suasana kebersamaan dan kerukunan tercermin di lingkungan SMAN 1 Tosari, hal ini dibuktikan dengan terselenggaranya kegiatan keagamaan begitu hidmat dan penuh dengan sikap toleransi dan kerukunan antar peserta didik, kegiatan yang diawali dengan lomba membuat penjor yang diikuti oleh semua peserta didik yang ada di sekolahan ini baik yang beragama Hindu maupun Islam dan kristen. Kegiatan lomba membuat penjor ini sangat kental dengan nilai-nilai toleransi dan kebersamaan yang terjadi antar peserta didik di sekoah ini. Karena dalam satu kelompok pesertanya campuran antara peserta didik yang beragama Islam dan peserta didik yang beragama Hindu mereka mengerjakan bersama saling membantu tanpa membedakan status keagamaan mereka, yang ada adalah kebersamaan yang terjalin dengan baik nan erat.

Demikian juga tidak jauh berbeda dengan SMA SPI merupakan sekolah menengah umum yang sama dengan sekolah-sekolah menengah pada umum lainnya, lokasi Sekolah ini di pinggiran kota Batu yang cukup jauh dari pusat keramian dan sebagai sekolah yang masih baru karena didirikan sekitar tujuh tahun yang lalu tepatnya pada tahun 2007 dan berlokasi di Jalan Pandanrejo No 1 desa Bumiaji, kecamatan Bumiaji kota Batu, Jawa Timur. ${ }^{2}$ Dalam konteks latar belakang agama, berdasarkan data

\footnotetext{
${ }^{1}$ Data Statistik SMAN 1 Tosari, Dokumentasi (18 mei 2019)

${ }^{2}$ Hasil Dokumentasi, Batu (Senin, 10 Mei 2016)
} 
statistik di SMA SPI siswa yang menganut agama Budha 9\%, Hindu 10\%, Kristen $23 \%$, Katholik $21 \%$, dan Islam $37 \%$. $^{3}$

SMA SPI ini didirikan bukan tanpa dasar yang kuat, akan tetapi dilatarbelakangi dari keprihatinan mendalam terhadap dahsyatnya efek kerusuhan yang berbasis suku, agama dan ras (SARA) pada tahun 1998-an yang bergejolak di muka bumi Negara Kesatuan Republik Indonesia.

Suasana "Indonesia mini" memang benar-benar terasa di sekolah ini. Hidup dalam kebersamaan memang sudah terbiasa dalam kultur para peseta didiknya dapat dilihat ketika para siswa menjadi recepsionis hotel SMA SPI kebetulan sudah waktu dluhur tiba, bagi peseta didik yang beragama non muslim mengingatkan kepada peseta didik muslim untuk beribadah sholat dluhur, dan pekerjaan sebagai recepsionis digantikan oleh peseta didik yang non muslim, begitu juga sebaliknya. Penelitian ini bertujuan mendeskripsikan, menganalisis dan menginterpretasikan tentang: (1) NilaiNilai Multikultural yang Terkandung Dalam Pendidikan Agama Islam Di SMAN 1 Tosari dan SMA SPI Kota Batu. (2) Desain Pendidikan Agama Islam dalam membangun kerukunan beragama Peseta didik Di SMAN 1 Tosari dan SMA SPI Kota Batu, (3) Proses Internalisasi Nilai-Nilai Multikultural Dalam Membangun Kerukunan Beragama Peserta didik Di SMAN 1 Tosari dan SMA SPI Kota Batu, dan (4) Model Internalisasi Nilai PAI Berbasis Multikultural Dalam Membangun kerukunan Beragama Peserta didik di SMAN 1 Tosari dan SMA SPI Kota Batu.

\section{METODE PENELITIAN}

Penelitian ini menggunakan kualitatif. Menurut Ghony penelitian kualitatif bertujuan untuk mendeskripsikan, menganalisis fenomena, peristiwa, aktivitas sosial, sikap, kepercayaan, serta persepsi dan pemikiran orang secara individu atau kelompok. ${ }^{4}$ Jenis penelitian ini adalah studi kasus (case study) dengan multisitus. Creswell menyatakan bahwa penelitian yang di dalamnya menyelidiki secara cermat suatu program, peristiwa, aktifivitas, proses, atau sekelompok individu. ${ }^{5}$ Jenis data ada dua, yaitu primer dan sekunder. Data primer diperoleh dalam bentuk kata-kata atau ucapan lisan (verbal) dan perilaku dari subjek (informan) yaitu; a) Kepala Sekolah SMAN 1 Tosari dan SMA SPI Batu, b) Waka Kurikulum, c) Waka Kesiswaan, d) Guru PAI SMAN 1 Tosari dan SMA SPI Batu, e) Siswa

${ }^{3}$ Data Statistik Siswa SMA Selamat Pagi Indonesia data Siswa Baru 2019/2020. di akses pada tanggal 31 Januari 2019

${ }^{4}$ M. Djunaidi Ghony \& Fauzan Al Manshur.Metodologi Penelitian Kualitatif. (Jogjakarta: ArrRuz Media, 2014), 89.

${ }^{5}$ John W. Creswell. Research Design Pendekatan Penelitian Kualitatif, Kuantitatif, dan Mixed. (Yogyakarta: Pustaka Pelajar. 2009), 20. 
SMA SPI Batu yang berkaitan dengan fenomena-fenomena serta peristiwa, atau aktivitas sosial, sikap, kepercayaan, persepsi orang dan pemikiran orang secara individu atau kelompok yang terjadi di SMA SPI. Sumber primer yaitu data yang diperoleh secara langsung dari masyarakat baik yang dilakukan melalui wawancara, observasi, dan alat lainnya. ${ }^{6}$ Seperti data yang berkaitan dengan nilai Nilai Nilai, Desain, Proses dan Model Internalisasi PAI berbasis multikultural dalam membangun kerukunan beragama di SMA SPI di Kota Batu.

Penentuan informan melalui dua langkah Pertama, dengan teknik purposive sampling. ${ }^{7}$ Kedua, dengan teknik snowball sampling ${ }^{8}$, Teknik bola salju ini dihentikan jika data yang diperoleh terkait internalisasi nilai-nilai multikultural siswa SMAN 1 Tosari dan SMA SPI Batu sudah sama dengan data yang telah diperoleh sebelumnya (point of theoretical saturation).

Ada tiga teknik dalam pengumpulan data: 1) wawancara mendalam: teknik ini digunakan untuk memperoleh data emik yaitu data yang berkaitan dengan implementasi nilai-nilai multikultural pada siswa; 2) observasi partisipan, dan 3) studi dokumentasi. Prosedur analisis menggunakan model interaktif menurut Miles dan Huberman yaitu: 1) reduksi data, yaitu menggolongkan data, serta membuang data yang tidak sesuai, dan mengorganisir data; 2) penyajian data, yaitu: menemukan bentuk dan pola hubungan yang bermakna serta memberikan adanya penarikan kesimpulan; dan 3) penarikan kesimpulan. Dengan menggunakan enam tahapan Creswell $^{9}$ yaitu (1) Mengolah data dan mengintrepetasikan data untuk dianalisis.(2) Membaca keseluruhan data dengan merefleksikan makna secara keseluruhan; (3) Menganalisis lebih detail dengan mengkoding data; (4) Menerapkan proses coding; (5) Menunjukkan bagaimana deskripsi dan tema-tema ini akan ditulis dalam narasi; dan (6) Menginterpretasikan data.

Kriteria pemeriksaan keabsahan data menggunakan naturalistik meliputi empat hal, ${ }^{10}$ sebagaimana menurut Lincoln dan Guba bahwa pelaksanaan pengecekan keabsahan data didasarkan pada empat kriteria yaitu derajat kepercayaan (credibitity), keteralihan (transferability), kebergantungan (dependability) dan kepastian (confirmability). ${ }^{11}$

${ }^{6}$ Joko Subagyo, Metode Penelitian dala.m Teori dan Praktik, (Jakarta: Rineka Cipta, 2011), 87

${ }^{7}$ Sugiyono, Metode Penelitian Kuantitatif Kualitatif dan $R \& D$, (Bandung: Alfabeta, 2008), 300

${ }^{8}$ Ibid.

${ }^{9}$ John W. Creswell. Op.Cit, 279.

${ }^{10}$ Yvona S.Lincoln dan Egon G.Guba, Naturalistic Incuiri, (Newbury Park:SAEG,1985), 301

${ }^{11}$ Ibid 


\section{PEMBAHASAN}

\section{Nilai-Nilai Multikultural yang Terkandung Dalam Pendidikan Agama Islam}

\section{Nilai Keimanan dan Ketaqwaan}

Setiap agama memiliki nilai-nilai khas (typical valuess), nilai ini istilahkan dengan nilai partikular, selain itu setiap agama juga memiliki nilai-nilai umum yang dipercaya oleh semua agama. Inilah yang disebut dengan nilai-nilai universal ${ }^{12}$. Nilai keimanan dan ketaqwaan merupakan nilai-nilai keagaman yang bersifat particular, yaitu nilai-nilai yang hanya diamalkan oleh pemeluk agama itu sendiri karena bentuk keyakinannya berbeda antara satu agama dengan agama lain, sedangkan nilai universal adalah nilai yang dimilik oleh semua. Hal ini sesuai dengan temuan di lapangan nilai keimanan dan ketaqwaaan masuk pada wilayah nilai particular sehingga implementasi nilai keimanan di SMAN 1 Tosari dilaksanakan dengan kegiatan keagamaan masing-masing, namun pelaksanaan kegiatan keagamaan peserta didik baik Islam dan Hindu di sekolah ini dilaksanakan secara besrsama-sama dalam waktu dan hari yang sama. Begitu juga di SMA SPI Kota Batu Implementasi nilai keimanan dilaksanana bersama-sama dimulai dengan Doa Pagi yang diikuti oleh semua peserta didik dari semua agama yaitu Islam, Kristen, Hindu dan Budha dilaksanakan bersama-sama. Kegiatan Doa Pagi ini dilaksanakan di Spiritual Garden. Spiritual garden adalah sebuah lokasi taman yang menyediakan fasilitas tempat Ibadah dari semua agama yang ada.

Pemetaan nilai menurut Abdullah dan Nurcholis Madjid di atas kalau ditarik pada temuan di lapangan ternyata memang nilai keimanan dan ketaqwaan masuk pada wilayah partikular, akan tetapi bukan berarti tidak bisa dilaksanakan secara bersama-sama, namun sebaliknya implementasi nilai keimanan dan ketaqwaan di kedua sekolah tersebut malah mampu dilaksanakan bersama-sama dalam waktu dan hari yang sama dan pada sekolah yang sama pula. Bahkan hal ini sudah menjadi kebiasan yang rutin dilaksanakan oleh para peserta didik SMAN 1 Tosari dan SMA SPI Kota Batu.

Senada dengan Abdullah, Nurcholis Madjid (dalam Zayadi) membagi nilai menjadi nilai Ilahiyyah dan nilai Insaniyah $^{13}$. Diantara nilai-nilai Ilahiyah adalah keimanan dan ketaqwaan. Implementasi nilai-nilai Ilahiyah di lapangan baik di SMAN 1 Tosari dan SMA SPI Kota Batu ternyata bisa dilaksanaan bersama-sama dalam kegiatan keagamaan bersama dan Doa

\footnotetext{
${ }^{12}$ Amin Abdullah, dalam Ainul Yaqin, Pendidikan Multikultural, Cross-Cultural Understanding untuk Demokrasi dan Keadilan, (Jogjakarta: Nuansa Aksara, 2005), xiv.

${ }^{13}$ Zayadi, Desain Pendidikan Karakter, (Jakarta: Kencana Pramedia Group,2001),95.
} 
Pagi bersama. Namun demikian bahwa kegiatan keagaman bersama dan doa bersama tersebut bukan sesuatu yang bersifat singkritis karena tidak ada pencampuradukan nilai keimanan dan ketaqwaan antar masing-masing agama, numun kegiatan bersama disini hanaya dilakukan dalam hari dan waktu serta sekolahan yang sama dengan tata cara peribadatan masingmasing yang dapat menumbuhkan kerukuan beragam antar peserta didik di kedua lembaga tersebut.

Dalam Konteks Ketaqwaan, Hasan menyatakan bahwa ketaqwaan bersangkut paut dengan aspek aksiologis, dan sistem nilai. Dalam agama Islam terdapat sistem nilai yang menjadi tuntunan bagi semua umat muslim terkait mana yang benar dan mana yang salah, mana yang baik dan mana yang buruk, mana yang boleh dan mana yang tidak diperbolehklan. Kesadaran aksiologis ini membuat pertanyaan-pertanyaan yang diajaukan oleh seorang mukmin tidak sekedar tentang "apa yang harus dilakukan" tetapi juga tentang apa yang sebaiknya dan semestinya untuk dilakukan". ${ }^{14}$

Mengacu pada pemikiran tersebut di atas maka implementasi nilai keimanan dan ketaqwaan yang dikembangkan di SMAN 1 Tosari dan SMA SPI Kota Batu berusaha mengejawantahkan "apa yang sebaiknya dan semestinya untuk dilakukan", dengan mengacu pada nilai persaudaraan antar peserta didik.

Dalam konteks kerukunan beragama disini harus dikembangkan konsep ukhuwah ubudiyah ini merupakan persaudaraan sesama makhluk dan sama-sama tunduk kepada Allah. Kedua, ukhuwah insaniyah atau ukhuwah basyariyah, yaitu persaudaraan sesama umat manusia tanpa terkecuali. Manusia yang memiliki motivasi dalam menciptakan persaudaraan hakiki yang dikembangkan atas prinsip nilai universal serta menjunjung tinggi nilai-nilai kemanusiaan, karena semua manusia pada hakikatnya sama di hadapan Allah, yang membedakan adalah ketaqwaannya sehingga kehidupan yang terbangun bersama ini dilanadasi saling menghormati, menghargai, toleransi tanpa harusa ada permusuhan diantara kehidupan bersama ini.

Nilai Ikhlas

Ikhlas menurut Al-Ghazali adalah sesuatu yang bersih dari campuran yang mencemarinya dinamakan sesuatu yang murni. Seperti firman Allah Swt dalam Surat An-Nahl:66. Apabila sesuatu perbuatan bersih dari riya' dan ditujukan bagi Allah Ta'ala maka perbutan itu dianggap murni (ikhlas) ${ }^{15}$ dari pendapat Imam Al- Ghazali tersebut bahwa

${ }^{14}$ Muhammad Tolchah Hasan, Dinamika Kehidupan Religius, (Jakarta, Listafarika Putra, 2000), 28.

${ }^{15}$ Imam Al-Ghazali, Mukhtasar Ihya' Ulumuddin, terj. (Jakarta: Pustaka Amani, 2007). 435. 
ikhlas merupakan perbuatan yang bersih dari riya' dan ditujukan bagi Allah swt. Sedangkan menurut Sidi Ghazalba mendifinisakan Ikhlas adalah suci dalam niat, bersih batin dalam beramal, tidak berpura-pura, lurus hati dalam bertindak, jauh dari riya" dan kemegahan dalam berlaku berbuat, mengharapkan ridha Allah semata-mata. ${ }^{16}$

Menurut Sentanu ${ }^{17}$ ikhlas merupakan Defaul Factory Setting manusia, yakni ada sejak manusia dilahirkan ke dalam dunia dengan fitrah murni dari Ilahi, namun manusia itu sendirilah yang suka mendiskonnya sehingga menjadi kurang kesempurnaannya. Husain bin Audah Al-Awayisyah mendefinisikan ikhlas seperti yang terdapat dalam surat Al-Insaan; 8-10, yaitu orang-orang ini sama sekli tidak melakukan amal shalih karena mengharapkan ucapan terimakasih dan pujian manusia, ketika mereka menyuguhkan makan, minuman atau bantuan, mereka sama sekali tidak mengharapkan bantuan apa-apa (dari manusia), tapi semua ini disertai dari rasa takut hanya kepada Allah Swt. ${ }^{18}$

Jadi ikhlas adalah sesuatu hal yang bersifat bathiniyah dan teruji kemurniannya dengan amalan-amalan saleh, Ikhlas juga merupakan perasaan halus yang tidak dapat diketahui oleh siapapun. Amal perbuatan adalah bentuk-bentuk lahiriyah yang dapat dilihat sedangkah ruh amal perbuatan itu adalah rahasia yaitu keikhlasan. ${ }^{19}$ Para serta didik baik yang ada di SMAN 1 Tosari dan SMA SPI Kota Batu sudah terbiasa untuk mengembangkan sikap kesehari-hariannya dengan ikhlas. Mereka menyadari bahwa perbedaan diantara mereka bukan sebagai penghalang untuk berbuat ikhlas, namun sebaliknya bahwa dengan keberagaman yang ada di kedua lembaga pendidikan tersebut para peserta didiknya malah termotivasi untuk berbuat ikhlas dengan jalan saling membantu dan menolong sesama peserta didik baik dalam mempersiapkan acara keagmaan maupun dalam kegiatan kegiatan yang lain.

Nilai Syukur

Menurut Quraish Syihab Hakikat Syukur adalah kebalikan dari kufur. Hakikat keber-syukur-an pada adalah menampakkan nikmat, sedangkan hakikat ke-kufur-an adalah menyembunyikan nikmat. Menampakkan nikmat berarti menggunakan nikmat sesuai pada tempat dan sesuai dengan yang dikehendaki oleh Allah SWT, juga menyebut-nyebut nikmat dan juga

\footnotetext{
${ }^{16}$ Sidi Gazalba, Asas Agama Islam (Jakarta:Bulan Bintang, 1975), 188

${ }^{17}$ Erbe Sentanu, Quantum Ikhlas Teknologi Aktivasi Kekuatan Hati (Jakarta: PT Elex Media Komputindo, 2008), 37

${ }^{18}$ Husain bin Audah Al-Awayisyah, Ikhlas Syarat Diteimanya Ibadah. (Bogor: Pustaka Ibnu Katsir, 2005). 49.

${ }^{19}$ Ibid., 16.
} 
pemberinya dengan lidah. ${ }^{20}$ Menurut Emmons, bahwa kebersyukuran merupakan kontruksi kognitif, emosi, dan perilaku. ${ }^{21}$ Sebagai kontruksi positif ditunjukkan dengan mengakui adanya kemurahan dan kebaikan hati atas berkah yang telah diterimanya. Sebagai konstruksi emosi rasa syukur itu ditandai adanya kemampuan mengubah respon emosi terhadap suatu peristiwa sehingga menjadi lebih bermakna.

Imam Ghazali membagi syukur menjadi tiga hal, meliputi: ${ }^{22}$ (1) Ilmu, yaitu pengetahuan tentang sesuatu nikmat dan pemberinya, serta meyakini bahwa semua nikmat yang diperoleh berasal dari Allah SWT. (2) Hal atau kondisi spiritual, yaitu pengetahuan dan keyakinan yang dimiliki akan melahirkan jiwa yang damai, aman, dan ketentraman. (3) Amal perbuatan, Amal ini berkaitan dengan aktivitas hati, lisan, dan anggota tubuh, hati yang berkeinginan untuk melakukan hal yang baik, lisan menampakkan dalam bentuk rasa syukur melalui pujian-pujian kepada Allah SWT, sedangkan anggota badan menggunakan nikmat-nikmat tersebut dengan kepatuhan, dan ketundukan dalam menjalankan perintah dan menjauhi larangan-Nya.

\section{Nilai Sabar}

Menurut Shihab, sabar memeliki arti menahan diri dari sesuatu hal yang tidak berkenan di hati, dan ketabahan. Lebih lanjut, Shihab membagi kesabaran menjadi dua. Pertama, sabar jasmani yakni kesabaran dalam menerima, patuh, dan melaksanakan, perintah-perintah agama yang melibatkan semua anggota tubuh. Kedua, sabar rohani yaitu kemampuan individu dalam menahan kehendak dan keinginan (nafsu) yang dapat mengantarkan kepada hal kejelekan seperti sabar dalam menahan marah, atau menahan nafsu seksual yang bukan pada tempatnya. ${ }^{23}$

Dalam pergaulan adakalanya kita tersinggung ketika mendengar atau mendapatkan perlakukan yang kurang menyenangkan dari orang lain. Namun demikian kita diwajibkan untuk bersabar menghadapinya, karna boleh jadi hal itu ternyata bisa mendatangkan banyak kebaikan bagi diri kita. Allah SWT berfirman dalam .(QS. al-Nisa': 19). Perbedaan latar belakang inilah seperti yang disebutkan pada ayat ini pihak sekolah memandang perlu sekali menanamkan nilai sabar kepada peserta didik, terutama dalam menghadapi dan menyikapi perbedaan latar belakang

${ }^{20}$ M. Quraish Syihab, Wawasan Al-Quran, Tafsir Maudhu'i atas Pelbagai Permasalahan Ummat, (Bandung: Mizan Mizan,1996). 216.

${ }^{21}$ Emmons, R. A., Thanks! How the new science of gratitude can make you happier, (Boston New York: Houghton Mifflin Company, 2007), 45.

${ }^{22}$ Imam Ghazali, Taubat, Sabar dan Syukur, Terjemah. Nur Hichkmah, (Jakarta: PT. Tintamas Indonesia, Cet.VI, 1983), 197-203.

${ }^{23}$ M. Quraish Shihab, Op-Cit, 181. 
peserta didik yang ada. Mengapa demikian karena warana perbedaan agama dan suku sangat kontras sekali di Sekolah ini apalagi menjelang perayaan hari raya-hari raya keagamaan baik perayaan hari raya umat Islam maupun perayaan hari raya umat Hindu dan juga upacara adat karo ${ }^{24}$ bagi masyarakat Tengger di sekolah ini. Salah satu upaya menciptakan kerukunan bersama pesrta didik di sekolah ini adalah dengan menanamkan sikap sabar khususnya dalam menghadapi dan menyikapi perbedanan latar belakan agama dan suku peserta didik yang ada.

\section{Nilai Demokrasi}

Agama yang seharusnya menjadi penyebar kasih sayang dan sumber keadilan bagi semua manusia tanpa pandang bulu telah disalah artikan oleh sebagaian kelompok dengan sikap dan tindakan anarkis dan sikap mersa pandangan dan prilaku keberagamannya yang paling benar dan paling sempurna, Jika agama memiliki kecenderungan untuk dimanipulasi dan disalah pahami oleh sebagian orang dan kelompok-kelompok beragama, demikian pula terjadi pada demokrasi ${ }^{25}$. Nilai demokrasi sangat nampak di kedua lembaga ini yang selalu mengedepankan musyawarah dalam memutuskan segala sesuatu baik dalam keorganisasian seperti Osis, Kepramukaan maupun dalam pembelajaran di dalam kelas..

\section{Nilai Keadilan}

Hakikat dasar kemanusiaan, termasuk kemestian menegakan keadilan, merupakan bagian dari sunatulloh, karena adanya fitrah manusia dari Allah dan perjanjian antara manusia dan Allah. Sebagai sunatullah, kemestian menegakan keadilan adalah kemestian yang merupakan hukum yang obyektif, tidak tergantung kepada kemauan pribadi manusia siapapun juga, dan immutable (tidak akan berubah) ia disebut dalam Al-Quran sebagai bagian dari hukum kosmis, yaitu hukum keseimbangan (al-Mizan) yang menjadi hukum jagad raya atau universe ${ }^{26}$.

Seperti pada acara Dharma Santhi dalam rangka merayakan Hari raya Nyepi bagi peserta didik yang beragama Hindu sehingga peserta didik Hindu masuk sekolah untuk merayakan kegiatan Dharma Santhi, namun peserta didik yang beragama Islam pun tetap masuk walaupun ada perayaan Dharma Santhi untuk peserta didik yang beragama Hindu. Peserta didik muslim masuk dengan mengadakan kegitan keagamaan hari itu juga yaitu

${ }^{24}$ Upacara Karo adalah perayaan besar desa, kata karo berarti dua atau kedua. Nama upacara Karo diambil karena upacara Karo diselenggarakan pada bulan Karo (ke dua) suku tengger. Upacara ini diselenggarakan sebagai wujud syukur atas berkah yang diberikan Tuhan sepanjang tahun

${ }^{25}$ Tim Indonesia Center For Civic Education, Demokrasi Hak Asasi manusia, dan Masyarakat Madani, (Jakarta: ICCE Uin Syarif dan Asia Fondation, 2006), 130.

${ }^{26}$ Nurcholis Madjid, Islam Gama Kemanusian, membangun Tradisi dan Visi Baru Islam Indonesia, (Jakarta: Paramadina, 1995). 184. 
dengan menggelar istighosah. Sehingga dalam waktu yang bersamaan ada dua acara keagamaan sekaligus yakni kegiatan keagmaan Dharma Santhi untuk peserta didik Hindu dan kegiatan istighozah untuk peserta didik yang beragama Islam.

Hal yang sama juga terjadi di SMA SPI Kota Batu karakter keadilan tercermin pada saat peserta didik dalam menjalankan kegiatan keagmaan bersama di Spiritual Garden, di tempat ini sarana tempat Ibadah dari masing-masing agama disediakan oleh pihak sekolah agar peserta didik bisa beribadah bersama. Selain itu peserta didik di SMA SPI ini juga mendapatkan hak dan kewajiban yang sama, serta adanya perlakuan yang sama terhadap semua peserta didik mendapatkan sanksi bagi yang melanggar tanpa pandang bulu. Hal ini juga tercermin pada sikap yang dilakukan oleh kakak Pembina dalam memutuskan suatu permasalah seperti pemberian sanksi pada peserta didik yang melanggar peraturan. Keadilan di sini terimplementasikan dalam bentuk sikap dalam menyelesaikan permasalahan tidak mudah menfonis, namun adanya klarifikasi terhadap kesalahan yang telah dilakukan. Bagi peserta didik yang telah melanggar tatatertib semuanya mendapatkan perlakuan yang sama.

\section{Nilai Kesetaraan dan kebersamaan}

Pada dasarnya relasi antara laki-laki dengan perempuan dalam perspektif Islam bersifat adil (equa). Konsep kesetaraan gender antara laki-laki dan perempuan dalam al-Qur'an, sebagai berikut: Pertama, Seorang laki-laki dan perempuan merupakan hamba Allah tidak ada perbedaan antara keduanya. Keduanya mempumyai potensi serta kesempatan yang sama untuk menjadi hamba baik (muttaqun). Kedua, jenis laki-laki dan perempuan sebagai khalifah (wakil) di muka bumi. Tujuan diciptakannya manusia di muka bumi untuk mengabdi kepada Allah SWT serta tumduk dan patuh kepada-Nya (Qs. al-Baqarah:[2]:30) dan (Al-An'am:[6]:165. Ketiga, Laki-laki dan Perempuan sama-sama menerima adanya perjanjian primordial. Seorang manusia yang yang dilahirkan dari rahim ibunya, terlebih dahulu dia menerima perjanjian primordial dengan Tuhannya QS alA'raf $172^{27}$. Dalam ajaran Islam tanggung jawab individu dan kemandirian ada sejak berada dalam kandungan dan tidak dikenal adanya diskriminasi kelamin. Keempat, Laki-laki dan perempuan mempunyai potensi meraih prestasi. Tidak ada pembedaan antara laki-laki dan perempuanuntuk meraih peluang prestasi. Disebutkan dalam al-Quran Qs. an-Nisa[4] 124. Ayat ini memberikan pengertian bahwa konsep kesetaraan ideal yang memberikan ketegasan terhadap potensi dan prestasi individual, baik dalam aspek

\footnotetext{
${ }^{27}$ Muhammad Taufiq, Aplikasi MS. Quran In Word Kemenag, (Jakarta: Lajnah Pentashih Mushaf al-Quran Kemenag, 2013), 2.2.
} 
spiritual maupun karir profesional, tidak dimonopoli oleh satu jenis kelamin saja.

Implementasi nilai kesataraan di SMAN Tosari tidak membeda-bedakan antara laki-laki dan perempuan pada aktifitas kesehari-hariannya. Pasukan Pengibar Bendera pada acara 17 Agustus di kecamatan Tosari, memenuhi keterwakilan laki-laki dan perempuan bahkan ada keterwakilan dari peserta didik muslim dan Hindu. di SMA SPI Batu, bahwa di dalam setiap kamar di SMA SPI komposisi peserta didik yang menjadi anggota kamar cukup beragam, baik dari sisi agama, budaya, suku, bahasa, daerah serta adat istiadatnya. Mereka dapat hidup bersama, berdampingan, saling menghargai, dan menjaga kerukunan beragama Menurut Baidhawy terdapat beberapa katakteristik yang dibangun bersama yaitu belajar hidup dalam perbedaan, membangun saling percaya. Memelihara saling pengertian, menjunjung sikap saling menghargai, terbuka dalam berpikir, apresiasi, interpedensi, resolusi konflik, dan rekonsiliasi nirkekerasan. ${ }^{28}$

Nilai Inklusif

Sikap inklusif yang diimplementasikan dan dikembangkan di kedua sekolah tersebut tercermin dari kebiasaan sikap terbuka menerima perbedaan dari perbedaan, suku, budaya, tradisi bahkan agama. hal ini sesuai dengan teory inklusif yang dikemukakan oleh Alwi Sihab bahwa: "Memaknai nilai inklusif dengan Islam inklusif yaitu sikap terbuka dalam beragama. Inklusif merupakan lawan dari eklusif. Dengan sikap berislam yang inklusif, seorang muslim diharapkan menyadari adanya nilai-nilai kebenaran dan kebaikan yang juga ditawarkan dan diajarkan agama lain. Seorang muslin harus yakin bahwa agama yang dianutnya adalah agama yang paling benar, namun dalam keseharian ia tidak menunjukan sikap"Sok benar" atau "mau menang sendiri", hal ini terutama dalam konteks pergaulan sesama manusia yang dalam Islam dikenal dengan Hablum minan nas. Inti dari sikap inklusif adalah tidak boleh merasa benar, tapi juga tidak memaksa kebenaran yang diyakini itu kepada orang lain. ${ }^{29}$ Abdullah membagi nilai dalam agama itu menjadi dua. Yaitu nilai partikular dan nilai Universal. Setiap agama di dunia memiliki nilai-nilai khas (typical valuess) yang terdapat pada masing-maasing agama, nilai ini istilahkan dengan nilai partikular, selain itu setiap agama juga memiliki nilai-nilai umum yang dipercaya oleh semua agama. Inilah yang disebut dengan nilai-nilai universal. ${ }^{30}$ Nilai partikular adalah nilai agama yang dilaksanakan sendiri

${ }^{28}$ Zakiyuddin Baidhawy, Pendidikan Agama Berwawasan Multikultural, (Jakarta: Erlangga, 2005), 78-84.

${ }^{29}$ Alwi Sihab, Multikultural dalam Agama-Agama, (Jakarta: Bumi Aksara, 1997), 102.

\footnotetext{
${ }^{30}$ Amin Abdullah, dalam Ainul Yaqin, Op.Cit, ,xiv.
} 
oleh pemeluknya sedangkan nilai universal adalah nilai-nilai agama yang pemeluk agama lain itu juga melaksanakannya seperti nilai multikultural.

Nilai-inklusif peserta didik disini melalui kegiatan perayaan-perayaan keagamaan seperti pada pelaksanan perayaan hari raya Nyepi dengan acara Dharma Santhi yang dilaksakan di sekolah ini, terlebih dahulu diadakan lomba membuat Penjor (kerajinan dari janur) dalam rangka perayaan hari Raya Nyepi. Pesertanya semua peserta didik dari masing-masing kelas dengan demikian tentunya peserta didik muslim pun mengikuti lomba membuat penjor.

Hal tersebut di atas diperkuat oleh Hasan tentang pentingnya nilai inklusif, kasih sayang, toleransi dan menghargai perbedaan adalah: bahwa adanya konflik sosial yang menimbulkan keterpurukan di negeri ini dikarenakan oleh kurang adanya kemauan untuk saling menerima dan menghargai adanya perbedaan, ide, pendapat, dan karya dan jerih payah yang dilakukan orang lain, dan kurangnya kemauan untuk melindungi yang lemah dan tidak berdaya, menyayangi terhadap sesama manusia, kurangnya kesetiakawanan sosial, dan tumbuhnya sikap egois serta kurang perasaan atau kepekaan sosial" 31

\section{Nilai Kemanusiaan}

Islam adalah agama yang menjunjung tinggi nilai-nilai kemanusiaan. Hal ini tercermin dalam sifat Universalisme Islam yang menjamin manusia baik secara perorangan maupun secara kelompok. Kelima jaminan dasar itu tersebar dalam literatur hukum agama (al-Kutub al fiqhiyyah) lama, yaitu jaminan dasar akan (1) keselamatan fisisk warga masyarakat dari tindakan badani diluar ketentuan hukum, (2) keselamatan keyakinan agama masingmasing, tanpa ada paksaan untuk berpindah agama, (3) keselamatan keluaraga dan keturunan, (4) keselamatan harta benda dan milik pribadi diluar prosedur hukum, dam (5) keselamatan profesi ${ }^{32}$. .

Interaksi yang dibangun di SMAN Tosari di SMA SPI dalam kehidupan sehari-sehari merupakan interaksi atas dasar nilai kemanusian, interaksi yang dibangun atas dasar nilai kemanusian inilah sebenarnya yang bisa mempersatukan dan merukunkan peserta didik dari masing-masing lembaga pendidikan tersebut bisa berjalan dengan harmonis dan kondusif. Interasksi yang demikian inilah akan melahirkan sikap saling tolong menolong, mengasihi, saling membantu walaupun para peserta didik tersebut sebenarnya dari latar belakang yang berbeda baik dari latar belakan

${ }^{31}$ Muhammad Tolchah Hasan, Pendidikan Multikultural Sebagai Opsi Penanggulangan Radikalisme, (Malang: Lembaga Penerbit Universitas Islam malang, 2016), 19

${ }^{32}$ Abdurrahman Wahid dalam Kontektualisasi Doktrin Islam Dalam Sejarah, Editor Budy Munawar Rahman, (Jakarta: Paramadina. 1995), 546. 
agama dan suku serta bahasanya. Mereka melakuakn sikap yang demikian dilandasi dengan nilai kemanusian yang dapat membantu membangun kerukunan umat beragama peserta didik, hal ini bisa dilahat pada interaksi kegiatan keagamaan yang saling membantu antara satu dengan yang lain walaupun beda agama.

\section{Nilai Taaruf}

Karakter saling mengenal (at Taaruf) merupakan pintu gerbang sebagai proses interaksi, antar individu, budaya, kelompok dalam suatu masyarakat yang tidak memperhatikan suku, budaya, ras, agama dan bahasa. Karakter Taaruf menurut ar Rozi dalam tafsirnya surat Al Hujurat ayat 13 menjelaskan bahwa kesediaan saling mengenal tidak boleh dihambat atau dihalangi oleh perbedaan latar belakang warna kulit, bahasa, suku, ras maupun agama, karena menurutnya kemuliaan dan martabat seseorang bukan di raih oleh orang tertentu dalam artian orang yang memiliki kulit putih atau kulit hitam, namun diperoleh dari ilmu, dan amal perbuatanya.

Kaitannya dengan ayat ini, adanya perbedaan ras, agama, suku etnis merupakan salah satu factor sebagai pemicu adanya konflik, pada ayat tersebut tidak ada perbedaan antara ras yang satu dengan yang lain. Ras itu dapat berbentuk berbagai macam, seperti perbedaan variasi penduduk atas dasar tampilan fisik, seperti rambut, mata, warna kulit, bentuk tubuh yang secara tradisional ada tiga, yakni Kaukasoid, Negroid dan Mongoloid. ${ }^{33} \mathrm{Di}$ luar ras sebagai variasi penduduk, ras juga menyatakan identitas berdasarkan, 1) Pemilikan perangai, 2) kualitas perangai tertentu dari suatu kelompok penduduk, 3) menyatakan kehadiran setiap kelompok penduduk berdasarkan geografi tertentu, 4) menyatakan tanda-tanda aktivitas suatu kelompok penduduk berdasarkan kebisaaan, gagasan dan cara berpikir, dan 5) sekelompok orang yang memiliki kesamaan keturunan, keluarga, klan atau hubungan kekeluargaan. ${ }^{34}$ Perbedaan ras memungkinkan manusia mengenal langsung akan wilayah asal atau bangsa mereka. Cara hidup suatu kelompok pun memberi indikasi pembentukan ras-ras tertentu. Kalau tidak ada tujuan pada penciptaan itu, maka mustahil Allah menyebutkan perbedaan ini. Tetapi perbedaan ini sengaja dibentuk oleh Allah SWT, atau dengan sebutan lain adalah sunnatullah.

Berdasarkan dari pemahaman ayat al Hujuraat ayat 13tersebut, maka dapat digunakan sebagai dasar multikulturalisme Islam yang menekankan

${ }^{33}$ Ras adalah suatu kategori atau pengelompokan sejumlah orang berdasarkan (terutama) karakteristik fisik tubuh, seperti warna kulit dan lain sebagainya.Pembagian ras itu berdasarkan ras-ras yang ada di dunia saat ini, lihat. M.S. Alo Liliweri, Prasangka Konflik: Komunitas Lintas Budaya Masyarakat Multikultur, Cet. II, (Yogyakarta: LKiS 2009), 19.

${ }^{34}$ Ibid, 19. 
nilai karakter inklusif berupa saling mengenal yang merupakan pintu gerbang proses interaksi antar individu dan/atau kelompok. Lebih dari itu, karakter saling mengenal juga merupakan indikasi positif masyarakat plural untuk bisa saling menghormati dan menerima perbedaan sehingga memberikan akses ke langkah berikutnya membangun masyarakat multikultural melalui karakter inklusif seperti toleransi, moderat, tolongmenolong dan harmoni yang merupakan akar nilai inklusif multikulturalisme dalam esensi Islam. ${ }^{35}$

\section{Tawasuth}

Sikap moderat ini menjadi sebuah identitas umat Islam $^{36}$ sebagaimana ditegaskan dalam Q.S [2]:143. Penafsiran dari beberapa ahli tentang sikap/karakter moderat, sebagai berikut ${ }^{37}$ : Menurut Ibnu 'Asyur kata "wasath" dengan dua makna. Pertama, secara lughowi, kata wasath rartinya sesuatu yang berada di tengah, atau sesuatu yang memiliki dua ujung yang ukurannya sebanding atau sama. Kedua, Istilahi makna wasath; adalah nilai-nilai Islam yang dibangun dengan cara berfikir yang lurus dan tengah-tengah, tidak berlebih-lebihan dalam hal apapun. Sedangkan makna "ummatan wasathan" dalam surat Q.S. [2]:143 merupakan umat yang adil dan terpilih. Yakni, umat Islam tersebut adalah umat paling sempurna agamanya, paling baik akhlaknya, paling utama amalnya. Allah SWT. telah menganugerahkan ilmu, budi pekerti, keadilan, dan kebaikan yang tidak dianugerahkan kepada umat lain. Maka dari itu, mereka (umat Islam) menjadi "ummatan wasathan", umat yang sempurna dan adil yang menjadi saksi bagi seluruh manusia di hari kiamat nanti. ${ }^{38}$.

Dengan demikian dari pendapat Ibnu Asyur di atas maka sikap/karakter at Tawassut/moderat adalah sifat terpuji yang terletak di tenga-tengah antara dua sikap yang mengandung ekstrimitas seperti pemberani yang berada diantara sikap penakut dan sembrono. Sikap murah hati diantara sikap kikir dan boros.

Senada dengan pendapat di atas, As Sa'rowy ${ }^{39}$ menyatakan tentang pengertian tawasut dari perspektif teologis, yaitu bahwa dalam teologi Islam terdapat konsep yang moderat. Di dalam aqidah manusia ada yang tidak memercayai tuhan sama sekali (atheis) namun ada yang memercayai tuhan banyak (polytheis). Islam memiliki sikap tawasut "mempercayai bahwa

\footnotetext{
${ }^{35}$ Muhammad Tholhah Hasan, Op. Cit, 41.

${ }^{36} \mathrm{Ibid}, 63$.

${ }^{37}$ Ibid, 63-65

38 Ibnu 'Âsyûr, Muhammad at-Thahir,At-Tahrîr wa al- Tanwir,
}

(Tunis: ad-Dar Tunisiyyah,1984), 17-18

39 Muhammad Mutawali al Sya'rowi, Tafsir Al-Sa'rowi, (AL-Azhar. Ahbarul Yaum, 1991), 626 
tidak ada tuhan selain Allah Yang Maha Esa tidak bersekutu" dalam aqidah manusia dalam arti bahwa orang Islam beraqidah di antara kedua aqidah Atheis dan polytheis. Hal ini sebagaimana menurut Yusuf menyatakan bahwa Moderasi Islam di bidang syari'ah tampak sekali terlihat sifat wasaathiyah dan keseimbangan yang menyangkut berbagai persoalan yaitu: (1) antara Ketuhanan dan Kemanusiaan, (2) antara Idealitas dan Realitas, (3) antara Tahlil dan Tahrim, (4) antara Kemaslahatan Individu dan Kolektif, (5) antara Ketegaran dan Kelenturan. ${ }^{40}$ Selanjutnya Ibnul Qoyyim dalam kitab Madaarij as Salikin mengartikan sikap tawasut itu merupakan sikap yang berada di posisi tengah-tengah. Agama Allah selalu berada di tengahtengah antara sikap menghindar dan masuk berlebih-lebihan.

\section{Nilai Tasaamuh}

Ada beberapa hal yang bisa dijadikan sebagai azas pemberlakuan konsep toleransi (tasamuh) dalam Islam, antara lain adalah: Pertama, bahwa manusia itu adalah makhluk yang mulia apapun agama, kebangsaan dan warna kulitnya. (QS. Al-Isra':70) ${ }^{41}$. Kedua, perbedaan manusia dalam Islam bahwa memeluk agama adalah karena kehendak Allah, dalam hal ini ajaran Islam telah memberikan kepada penganutnya kebebasan serta usaha (hak memilih) untuk melaksanakan atau meninggalkan sesuatu (QS. Hud:118). Ketiga, orang muslim tidak diberikan hak untuk menghisab orang kafir karena kekafirannya. (QS.al-Hajj: 68-69). Keempat, Sebagai orang yang beriman, Allah menyuruh untuk berlaku dan berbuat adil serta menyerukan agar berakhlak mulia walaupun terhadap kaum kafir, membenci kezaliman dan menghukum mereka yang bertindak zalim, walaupun kezaliman tersebut dilakukan oleh orang muslim terhadap orang kafir. (al-Maidah:8) ${ }^{42}$ Kelima, Islam tidak memaksakan mereka menjadi muslim apalagi dengan kekerasan. (QS. Al-Baqarah:256) Islam adalah agama dakwah. Dakwah Islam dilakukan dsengan cara yang ramah dan bijaksana. Islam menyadari bahwa keragaman manusia merupakan kehendak Allah.

Dalam bahasa Arabnya toleransi adalah as-samahah yakni konsep untuk menggambarkan sikap saling hormat-menghormati, saling bekerjasama antara kelompok-kelompok masyarakat yang berbeda-beda secara bahasa, budaya, politik, suku, etnis, bahkan agama. Oleh karenaya toleransi merupakan konsep mulia nan agung yang menjadi bagian sepenuhnya dari ajaran agama-agama yang ada.

Islam memiliki konsep yang jelas tentang toleransi. "Tidak ada paksaan dalam agama", "Bagimu agama-mu, dan bagi-ku agamaku". Selain ayat

${ }^{40}$ Yusuf, A. Moderasi Islam Dalam Dimensi Trilogi Islam (Akidah, Syariah, Dan Tasawuf). AL MURABBI, 3(2), 2018. 203-216

${ }^{41}$ Taufiq Muhammad, Op.Cit.

${ }^{42}$ Ibid. 
tersebut, ada ayat-ayat lain dalam al-Qur'an dan hadits tentang toleransi dan praktiknya dalam sejarah Islam. Dengan demikian toleransi dalam Islam bukan hal yang baru ada.

\section{Nilai Taawun}

Sikap saling menolong merupakan ciri khas umat muslim semenjak masa Rasulullah SAW. Di masa Rosulullah tak ada seorang muslim yang membiarkan muslim yang lain kesusahan, hal ini terlihat jelas pada saat terjadinya peristiwa hijrah umat muslim dari Makkah ke Madinah, pada peristiwa itu kaum ansor atau Muslim Madinah menerima dengan baik, lapang dada terhadap kedatangan kaum muhajirin yang seiman dengan sambutan yang hangat penuh kekeluargaan, mempersilahkan segalanya bagi para muhajirin.

Implementasi nilai ta'awun dalam kehidupan sehari peserta didik di SMAN Tosari ini sangat kental sekali seolah olah sudah menjadi bagian dari atmosfir akademik yang dibangun di sekolah ini, para peserta didik sudah terbiasa untuk saling tolong menolong atau bantu-membantu antar para peserta didik tanpa harus memandang apakah peserta didik tersebut yang dibantu satu agama dengannya atau satu suku dengannya, tolong menolong dalam mempersiapkan acara perayaan keagamaan agama lain dengan senang hati mereka lakukan. Nilai taawun juga diimplementasikan di SMA SPI pada setiap mau beribadah baik di asrama, di Spriritual Garden dan juga pada setiap moment acaara keagamaan peserta didik disini saling tolong menolong dan membantu persiapan acara perayaannya..

\section{Nilai Tawazun}

At Tawazun menurut Hasan yaitu sikap dan orientasi hidup yang diajarkan Islam, sehingga manusia tidak terjebak esktrimitas dalam hidupnya, bukan semata-mata mengejar kehidupan ukhrowi dengan mengabaikan kehidupan duniawi atau sebaliknya. ${ }^{43}$ Senada dengan pendapat di atas, menurut Fadeli bahwa tawazun yaitu sikap seimbang dalam berkhidmat demi terciptanya keserasian hubungan antara sesama umat manusia dan antara manusia dengan Allah SWT. ${ }^{44}$ Ini sesuai dengan Qur'an Surat al Qhasah 77; Dalam konteks Pendidikan di SMAN 1 Tosari yaitu pendidikan yang seimbang antara pendidikan yang berorientasi kepada masa depan peserta didik didunia yaitu dengan membekali ilmu pengetahuan (kognitif), sikap/kecakapan (afektif) dan ketrampilan (psichomotoric) dan mebekali peserta didik dengan penguatan nilai pendidikan Agama untuk membangun peserta didik yang beriman, bertaqwa serta berbudi pekerti yang luhur dan juga mengembangkan kesalehan

${ }^{43}$ Muhammad Tholhah Hasan, Op.Cit, 70.

${ }^{44}$ H. Soeleiman Fadeli, M. Subhan, Antologi NU, Sejarah-Istilah-Amaliah-Uswah, Jawa Timur: LTNU, 2007), 13. 
individu (hablum minallloh) dan kesalahan sosila (Hablum min an-Nas). Begitu juga nilai tawazun yang diimplementaasikan di SMA SPI Kota Batu yaitu peserta didik di sekolah ini disamping mendapatkan materi pelajaran di dalam kelas, namun mereka juga mendapatkan praktek pembelajaran dilaboratorium Transformer, memang sistem pendidikan di sekolah ini didesain hampir mirip dengan pendidikan kejuruan dengan metode pendekata Study Ekperince Learning (SEL). Disamping itu pendidikan di sekoah ini mengembangkan visi pendidikannya yaitu menyelenggarakan pembelajaran bidang keimanan dan ketaqwaan/ketaatan (imtaq) dengan mebiasakan beribadah bersama-sama sesuai jadwal masing-masing. Dengan demikian bahwa orientasi yang seimbang antara pendidikan yang berorientasi pada keberhasilan di dunia dan di akhirat, serta pendidikan yang mengembangkan dimensi kognitif, afektif dan psikomotorik. Disamping penegembangan potensi peserta didik melalui pendekatan PAKSA ((Prayer, Atitude, Knowledge, Skill, Action.)

Nilai Kekeluargaan

Dalam Al-Qur'an dijumpai beberapa kata yang mengarah pada "keluarga". Ahlul bait disebut keluarga rumah tangga Rasulullah SAW (alAhzab 33). Menurut Mufidah bahwa keluarga merupakan salah satu lembaga sosial yang didasarkan untuk mencetak kualitas dan membentuk karakter manusia. Sampai saat ini masih menjadi keyakinan dan harapan bersama bahwa lingkungan keluarga senantiasa dapat diandalkan sebagai lembaga ketahanan moral, akhlak al-karimah, pembentukan akhlak, dalam konteks bermasyarakat, bahkan baik buruknya generasi bangsa ditentukan pembentukan pribadi dalam keluarga. Di sinilah keluarga memiliki peran yang strategis dalam untuk memenuhi harapan tersebut. ${ }^{45}$

Implementasi nilai kekeluargaan di SMAN 1 Tosari tercermin pada kehidupan bersama setiap harinya dan setiap acara kegiatan yang ada di sekolahan, baik kegiatan Osis maupun kegiatan keagaman. Seperti pada acara keagamaan Dharma Asrama dan Istighozah peserta didik SMAN 1 Tosari datang dengan memakai busana Muslim dan Muslimah bagi yang beragama Islam dan berpakian sembahyang Umat Hindu bagi peserta didik yang beragama Hindu, mereka datang saling bertegur sapa, bercanda dan berkumpul dibeberapa tempat walaupun tampak kontras sekali dari segi pakiannya karena mereka memakai pakian identitas keagamaan masingmasing, namun demikian hal ini tidak menjadi penyekat dan pembatas bagi mereka, tetap berbaur walaupun beda agama dan pakian yang dikenakan.

Nasionalisme dan cinta tanah air

\footnotetext{
${ }^{45}$ Mufidah Ch, Psikologi Keluarga Islam Berwawasan Gender, (Malang:UIN Press), 6.
} 
Kata nation berasal dari kata nascie yang memiliki arti dilahirkan. Jadi kata nation adalah bangsa yang dipersatukan karena adanya kelahiran. Sedangkan secara antropologis dan sosiologis Yatim menyatakan bawah bangsa merupakan suatu persekutuan hidup yang berdiri sendiri dan masing-masing anggota persekutuan hidup tersebut merasa satu kesatuan ras, satu bahasa, agama, sejarah dan adat-istiadat. ${ }^{46}$ Lebih lanjut menurut Stoddard "Nasionalisme adalah suatu keadaan jiwa, suatu kepercayaan yang dianut oleh sejumlah besar manusia sehingga mereka membentuk suatu kebangsaan dalam bentuk kebersamaan" 47

Nilai nasionalisme menurut Kartodirjo, antara lain: (1) kesatuan (unity); (2) kebebasan (liberty); (3) kesamaan (equality); (4) kepribadian (individuality) dan (5) prestasi (performance).$^{48}$ Selain itu Moesa dalam penelitiannya mengatakan bahwa nilai-nilai nasionalisme merupakan rasa keterikatan sekelompok orang (alash'abiyah) yang memiliki kesamaan tujuan untuk membangun suatu sistem tatanan kehidupan. Nilai-nilai nasionalisme ini menurutnya dibangun atas pluralitas, persaudaraan, solidaritas dalam keberagaman, kesederajatan dan cinta tanah air. ${ }^{49}$ Menurut Ibnu Khaldun yang dikutip oleh Moesa bahwa nilai-nilai nasionalisme terdiri dari cinta tanah air, kebersamaan yang disertai jiwa patriotism dan juga perlawanan melawan penjajah ${ }^{50}$. Lebih lanjut Yatim mengatakan nilai nasionalisme sudah dianggap muncul manakala suatu bangsa memiliki citacita yang sama untuk mendirikan suatu negara dan bangsa. ${ }^{51}$

Semangat Nasionalisme dan cinta tanah air bagi para peserta didik di SMAN Tosari dan SMA SPI Kota Batu memnag harus ditanamkan sedini mungkin, karenaa dari semangat nasionalisme dan cita tanah air ini para peserta didik akan mempunyai sikap seperti yang diugnkapkan oleh Kartodirjo, antara lain: (1) kesatuan (unity); (2) kebebasan (liberty); (3) kesamaan (equality); (4) kepribadian (individuality) dan (5) prestasi (performance). ${ }^{52}$

Berdasarkan hasil analisis temuan di atas, bahwa nilai yang menjadi core dalam membangun kerukunan beragama peserta didik adalah kekeluargaan. Ukhuwah diartikan lebih luas tidak hanya ada hubungan

46 Badri Yatim, Soekarno Islam dan Nasionalisme (Jakarta: PT. Logos Wacana Ilmu, 1999), 57.

${ }^{47}$ Ibid.

16.

${ }^{48}$ Sartono. KartodirjoPembangunan Bangsa. (Yogyakarta: Aditya Media. 1993),

${ }^{49}$ Ali Maschan Moesa. Nasionalisme Kiai. (Yogyakarta: LKis. 2007), 307

${ }^{50}$ Ibid, 216

${ }^{51}$ Badri Yatim. Op. Cit, 59.

${ }^{52}$ Kartodirjo Sartono, Pembangunan Bangsa. (Yogyakarta: Aditya Media. 1993), 
keluarga, namun lebih dari itu yaitu orang yang segolongan, sepaham, seagama,sederajat. ${ }^{53}$ Hal ini sejalan dengan pendapat Shihab bahwa persaudaraan (ukhuwah) diartikan sebagai bentuk persamaan dan kesesuaian dengan pihak lain, baik persamaan keturunan dari ibu, bapak, maupun keduanya, serta dari persusuan, juga mencakup persamaan salah satu dari unsur seperti suku, agama, profesi, dan perasaan. ${ }^{54}$

Persaudaraan (ukhuwah) Menurut Quraish Shihab yang mengacu pada al- Quran, ada 4 bentuk persaudaraan yaitu (1) Ukhuwah Ubudiyah, (2) Ukhuwah Insaniyyah atau (basyariyyah), (3) Ukhuwah Wathaniyah wa an-Nasab, (4) Ukhuwah fi ad-din al-Islam (persaudaraan antara sesama muslim). ${ }^{55}$ Pertama, Ukhuwah Ubudiyah ini merupakan persaudaraan sesama makhluk dan sama-sama tunduk kepada Allah. Kedua, Ukhuwah insaniyah atau Ukhuwah basyariyah, yaitu persaudaraan antar umat manusia tanpa terkecuali. Manusia yang memiliki motivasi dalam menciptakan persaudaraan hakiki yang dikembangkan atas prinsip nilai universal serta menjunjung tinggi nilai-nilai kemanusiaan, karena semua manusia pada hakikatnya sama di hadapan Allah, yang membedakan adalah ketaqwaannya. Ketiga, Ukhuwah Wathaniyah wa an-Nasab, persaudaraan dalam jalinan sebangsa dan setanah air walaupun tidak seagama. Konsep ini berdasarkan pada ayat al-Qur'an surat al-A'raf ayat 65 Ayat ini, sebagaimana menurut Quraish Shihab menjelaskan bahwa untuk memantapkan ukhuwah kebangsaan walau tidak seagama, pertama kali alQuran menggarisbawahi bahwa perbedaan adalah hukum yang berlaku dalam kehidupan ini. Selain perbedaan tersebut merupakan kehendak Allah, juga demi kelestarian hidup, sekaligus demi mencapai tujuan kehidupan makhluk di bumi. ${ }^{56}$

Senada dengan pendapat tersebut Suyuti menyatakan bahwa cerminan ukhuwah (wathoniyah) kebangsaan ini dapat dilihat dalam Piagam Madinah yang bertujuan untuk mewujudkan persatuan sesama warga, sesama masyarakat Madinah, yakni persatuan dalam bentuk persaudaraan penduduk Madinah sebagaimana tercantum dalam dalam pasal 24 pada piagam tersebut, yakni (orang-orang mukmin dan Yahudi bekerja sama menanggung pembiayaan selama mereka berperang $)^{57}$ ini mengindikasikan bahwa di dalam masyarakat Madinah ada jalinan kerjasama, tolong

${ }^{53}$ Departemen Pendidikan Nasional, Kamus Besar Bahasa Indonesia (Jakarta: Balai Pustaka, 2002), 1003.

${ }^{54}$ M. Quraish Shihab, Op.Cit, 486.

${ }^{55}$ M. Quraish Shihab, Membumikan al-Qur"an (Bandung: Mizan, 1998), 358.

${ }^{56}$ M. Quraish Shihab, Op.Cit, 491.

57 J. Syutuhi Pulungan, Prinsip-Prinsip Pemerintahan dalam Piagam Madinah; Dintinjau dari Pandangan al-Qur'an (Cet. II; Jakarta: PT. RajaGrafindo Persada, 1996), 146. 
menolong serta saling menjaga keselamatan dari ancaman luar. Keempat, Ukhuwah fi ad-din al-islam (persaudaraan antara sesama muslim). Berdasarkan pada al-Qur'an surat al-Hujuraat ayat 10 .

Dalam konteks kerukunan beragama disini harus dimunculkan konsep ukhuwah imaniyah, Alquran secara tegas menyatakan persaudaraan orang-orang yang memiliki keimanan, sebagaimana ditegaskan dalam ayat, 'Innamal mu'minuna ikhwatun, fa ashlihu baina akhawaikum...' Sesungguhnya orang-orang mukmin adalah bersaudara karena itu damaikanlah saudaramu/QS Al-Hujurat/49:10)

Ukhuwah imaniyah dalam konteks ini merupakan jaringan persaudaraan yang dilandasi persamaan keimanan seseorang terhadap Tuhan tanpa memandang bentuk-bentuk agama dan kepercayaan formal mereka selama kehidupan yang terbangun bersama ini dilanadasi saling menghormati, menghargai, toleransi tanpa permusuhan yang memeranginya didalam kehidupan bersama ini. Hal ini seperti yang sudah dilakukan para peserta didik di SMAN 1 Tosari dan SMA SPI Kota Batu.

\section{KESIMPULAN}

Hasil penelitian ini menunjukkan bahwa: (1) Nilai-Nilai Multikultural di Sekolah Menengah Atas Negeri 1 Tosari dan Sekolah Menengah Atas SPI memiliki nilai yang sama, walaupun terletak pada basis lingkungan yang berbeda. Adapun nilai tersebut meliputi; keimanan, ketaqwaan, keikhlasan, syukur, sabar, demokrasi, keadilan, kesetaraan, inklusif, kemanusiaan, taaruf, tasamuh, ta"wun, tawazun, kekeluargaan, cinta tanah air dan nasionalisme. (2) Desain Pendidikan Agama Islam dalam membangun Kerukunan Beragama pada kedua sekolah tersebut memiliki kesamaan pada berbasis kelas dan berbasis Kultur, Perbedaan desain terletak pada basis lingkungan/komunitas bagi Sekolah Menengah Atas Negeri 1 Tosari dan Berbasis Asrama, Transformer Center, spiritual garden di Sekolah Menengah Atas SPI Kota Batu. (3) Proses Internalisasi Nilai-Nilai Multikultural Dalam Membangun Kerukunan Beragama Peserta didik samasama melalui: (a) Moral Knowing (b) Moral Feeling, (c) Moral Action, dan (d) Moral Transenden. (4) Model internalisasi nilai di Sekolah Menengah Atas Negeri 1 Tosari dalam bentuk sinergitas lingkungan masyarakat dengan lingkungan sekolah yang sangat kuat sehingga mampu membentuk karakter siswa dalam membangun kerukunan beragama peserta didik. Sedangkan model internalisasi di Sekolah Menengah Atas SPI Batu dilakukan melalui sinergi kegiatan dan program yang ada di (1) asrama, (2) kelas, (3) lingkungan sekolah, (4) transformer center, dan (5) spiritual garden, yang dibiasakan secara integrative melalui metode penilaian PAKSA. Bangunan konseptual model Internalisasi Nilai PAI berbasis 
multikultural dalam membangun Kerukunan Beragama melalui pendekatan Pluralis Sosiologis dengan model Sinergi Integratif.

\section{DAFTAR PUSTAKA}

Abdurrahman Wahid dalam Kontektualisasi Doktrin Islam Dalam Sejarah, 1995, Editor Budy Munawar Rahman, Jakarta: Paramadina.

Ainul Yaqin, 2005, Pendidikan Multikultural, Cross-Cultural Understanding untuk Demokrasi dan Keadilan, Jogjakarta: Nuansa Aksara.

Ali Maschan Moesa, 2007. Nasionalisme Kiai. Yogyakarta: LKis.

Alwi Sihab, 1997. Multikultural dalam Agama-Agama, Jakarta: Bumi Aksara.

Badri Yatim, 1999. Soekarno Islam dan Nasionalisme Jakarta: PT. Logos Wacana Ilmu.

Departemen Pendidikan dan Kebudayaan, Kamus Besar Bahasa Indonesia Edisi Kedua, Jakarta:Balai Pustaka.

Djunaidi Ghoni \& Fauzan. 2012. Metodelogi Penelitian Kualitatif, Jogjakarta, Ar -Ruzz Media.

Emmons, R. A., 2007, Thanks! How the new science of gratitude can make you happier, Boston New York: Houghton Mifflin Company.

Erbe Sentanu, 2008, Quantum Ikhlas Teknologi Aktivasi Kekuatan Hati, Jakarta: PT Elex Media Komputindo.

Husain bin Audah Al-Awayisyah, 2005, Ikhlas Syarat Diteimanya Ibadah. Bogor: Pustaka Ibnu Katsir.

Ibnu 'Âsyûr, Muhammad at-Thahir, 1984, At-Tahrîr wa al- Tanwir, Tunis: ad-Dar Tunisiyyah.

Imam Al-Ghazali, 2007, Mukhtasar Ihya' Ulumuddin, terj. Jakarta: Pustaka Amani.

1983, Taubat, Sabar dan Syukur, Terjemah. Nur Hichkmah, Jakarta: PT. Tintamas Indonesia, Cet.VI.

Jhon W. Creswell, 2005. Eduation Research: Planing, Conducting, and Evaluating Quantitative an Qualitative Research;USA: Pearsoon Education, Inc.

Joko Subagyo, 2011, Metode Penelitian dala.m Teori dan Praktik, Jakarta: Rineka Cipta.

J. Syutuhi Pulungan, 1996. Prinsip-Prinsip Pemerintahan dalam Piagam Madinah; Dintinjau dari Pandangan al-Qur'an Cet. II; Jakarta: PT. RajaGrafindo Persada.

M. Quraish Shihab, 2002, Tafsir al-Misbah Pesan, Kesan dan Keserasian al-Qur'aJakarta: Lentera Hati. 
Hati . 2010. Membumikan Al-Qur'an Jilid 2, Jakarta: Lentera . 1998. Wawasan Al-Qur'an, Tafsir Maudhu'i atas Pelbagai Persoalan Umat, Cet. VIII Bandung: Mizan.

M.S. Alo Liliweri, 2009, Prasangka Konflik: Komunitas Lintas Budaya Masyarakat Multikultur, Cet. II, Yogyakarta: LKiS.

M, Subhan, Soeleiman Fadeli, 2007. Antologi NU, Sejarah-Istilah-AmaliahUswah, LTNU Jawa Timur.

Mufidah Ch, Psikologi Keluarga Islam Berwawasan Gender, Malang:UIN Press.

Muhammad Mutawali al Sya'rowi, 1991, Tafsir Al-Sa'rowi, AL-Azhar. Ahbarul Yaum.

Muhammad Taufiq, 2013. Aplikasi MS. Quran In Word Kemenag, Lajnah Pentashih Mushaf al-Quran Kemenag. V.2.2. 2013 QS. al-Hujuraat, 49:11.

Muhammad Tholhah Hasan, 2016. Pendidikan Multikkultural sebagai Opsi Penanggulangan Radikalisme, Malang:lembaga Penerbitan Universitas Malang.

Listafarika Putra.

2000. Dinamika Kehidupan Religius, Jakarta,

Nur Cholis Madjid, Islam Agama Kemanusian, membangun Tradisi dan

Visi Baru Islam Indonesia, Jakarta: Paramadina, 1995.

Sartono Kartodirjo, 1993. Pembangunan Bangsa. Yogyakarta:

Aditya Media.

Sidi GAzalba, 1978. Sistematika Filsafat, Buku IV Jakarta: Pustaka Bulan Bintang.

Sidi Gazalba, 1975, Asas Agama Islam, Jakarta:Bulan Bintang.

Sugiyono, 2008, Metode Penelitian Kuantitatif Kualitatif dan $R \& D$, Bandung: Alfabeta.

Tim Indonesia Center For Civic Education, 2006, Demokrasi Hak Asasi manusia, dan Masyarakat Madani, Jakarta: ICCE Uin Syarif dan Asia Fondation.

Yusuf, A. Moderasi Islam Dalam Dimensi Trilogi Islam (Akidah, Syariah, Dan Tasawuf). AL MURABBI, 3(2), 2018.

Zayadi, 2001. Desain Pendidikan Karakter, Jakarta: Kencana Pramedia Group.

Zakiyuddin Baidhowy, 2005. Pendidikan Agama Berwawasan multicultural Jakarta: Erlangga, 